\title{
Sustainable fisheries subsidies for small scale fisheries in Indonesia
}

\author{
${ }^{1}$ Andre Notohamijoyo, ${ }^{2}$ Adhi Setya Wiyata, ${ }^{2}$ Mustaidz Billah \\ \{andre.hamijoyo@gmail.com, adhisetya@dkp.or.id, mustaidz17@gmail.com\} \\ ${ }^{1}$ School of Environmental Science, Universitas Indonesia. Gedung Sekolah Ilmu Lingkungan, \\ Jl. Salemba Raya No. 4 Jakarta 10430 \\ ${ }^{2}$ Ministry of Marine Affairs and Fisheries, Jl. Medan Merdeka Timur No, 16 Jakarta 10110
}

\begin{abstract}
As a country with enormous fisheries resources, Indonesia face threats to sustainability of the resources which are suspected because of the implementation of fisheries subsidies that did not consider the resources. On the other side, government provide subsidies to alleviate poverty and improve fishermen's welfare. A number of countries, especially developed countries encourage the elimination of fisheries subsidies through WTO and other countries, especially developing countries opposed the proposal of the developed countries. Nevertheless, it is necessary to make a balance between community development and environmental protection in case of fisheries subsidies. This study reviews the implementation of fisheries subsidies in Indonesia. The research is based on a literacy study along with data and information on fishery subsidies that have been carried out so far by the Ministry of Marine Affairs and Fisheries as an authorized government agency. The results of the study indicate that there are benefits from providing subsidies to the welfare of fishermen and also support the sustainability of fisheries resources.
\end{abstract}

Keywords: fisheries subsidies, sustainable fisheries management, WTO, fisheries resources

\section{Introduction}

As the biggest archipelagic country in the world, Indonesia still face the threat caused by excessive, damage, illegal, unreported and unregulated fishing (IUUF) practices. The condition is suspected as a result of fisheries subsidies that do not consider the sustainability of fisheries resources.

In recent years, Indonesia's fisheries resources have jumped quite sharply. If in 2011 fishery resources reached 6.52 million tones ${ }^{1}$, currently the estimated fishery resources reach 12.54 million

${ }^{1}$ Minister of Maritime Affairs and Fisheries Decree No. 47/KEPMEN-KP/ 2016 concerning Estimation of Potential, Number of Catches Allowed, Level of Utilization of Fish Resources in the State Fisheries Management Area of the Republic of Indonesia 
tons ${ }^{2}$. Even though that the resources increased, it still faced the same problems due to the practice of overfishing, overcapacity, destructive fishing and IUUF. Overfishing is a situation in which the fishing in a region has exceeded the carrying capacity of the environment of fisheries resources in the region. ${ }^{3}$

Indonesia waters still have experienced overfishing and overcapacity. Overfishing and overcapacity condition allegedly caused by fisheries subsidies. The provision of subsidies in the fisheries sector by the government is considered by many parties contribute excessive fishing. Subsidies assessed spur businesses to increase their fishing efforts.

Schachermayer ${ }^{4}$ stated in his research that the subsidy does not have a positive impact on improving the welfare of fishermen and ecological protection. UNEP ${ }^{5}$ in its annual report entitled Fisheries Subsidies and Marine Resource Management: Lessons Learned from studies in Argentina and Senegal expressed the same thing that fisheries subsidies has no positive impact on the welfare of fishermen.

As an archipelagic state, Indonesia has a vast sea area and requires complex handling in its management. Indonesian fishermen still need support from the government for the management of both policies and facilitation. Indonesia marine waters are divided into 11 fisheries management area (FMA) as set forth in the Regulation of the Minister of Marine and Fisheries no. 1 of 2009 on Regional Fisheries Management of the Republic of Indonesia.

The division can be seen in the figure 1 below.

2 Minister of Maritime Affairs and Fisheries Decree No. 50/KEPMEN-KP/ 2017 concerning Estimation of Potential, Number of Catches Allowed, Level of Utilization of Fish Resources in the State Fisheries Management Area of the Republic of Indonesia

${ }^{3}$ Fauzi, Achmad (2011). Ekonomi Perikanan. Jakarta: Penerbit Kompas Gramedia

${ }^{4}$ Schachermayer, Carolin I. Mondaca, Aburto Jaime, Cundill, Georgina, Lancellotti, Carlos, Domingo \& Tapia (2011).

An Empirical Analysis of the Social and Ecological Outcomes of State Subsidies for Small-Scale Fisheries: A Case

Study from Chile. Ecology and Society 16(3): 17

5 United Nations Environmental Programme. Fisheries Subsidies and Marine Resources Management: Lessons learned

from Studies in Argentina and Senegal, 2001. 


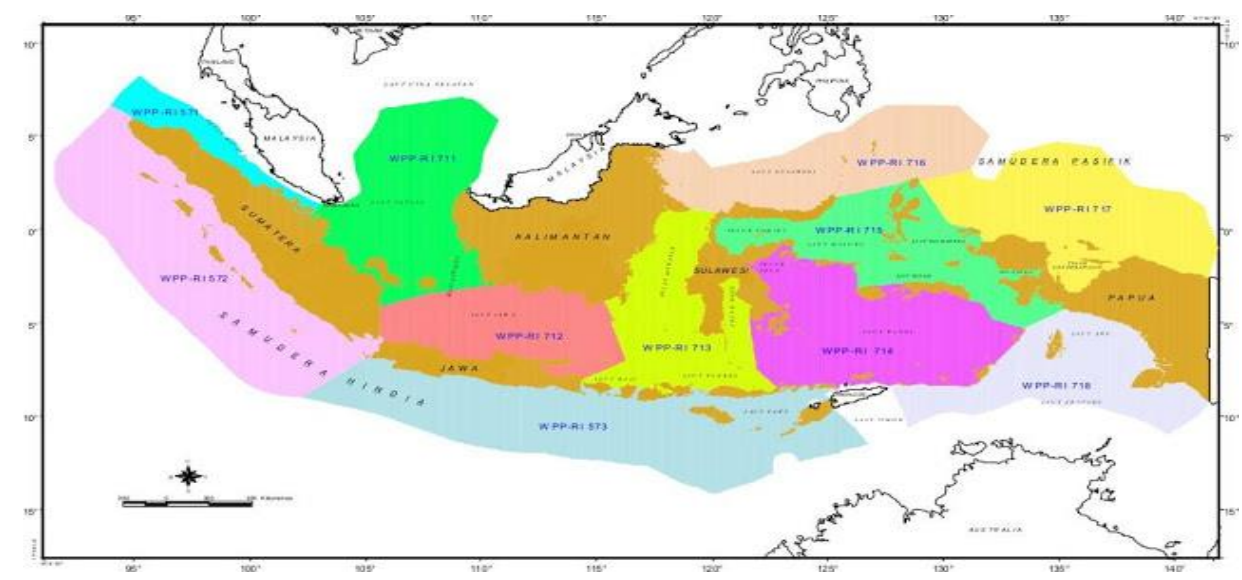

Fig.1 Indonesia Fisheries Management Area

In some countries fisheries subsidies are prohibited because it has proven to cause overfishing and overcapacity. Nevertheless, several countries including Indonesia still retain subsidies for reasons of poverty alleviation. In Indonesia subsidies deemed not affect the condition of overfishing and overcapacity due to the structure of fisheries in Indonesia which are dominated by artisanal or small-scale fisheries thus considered not damage the environment. Table 1 shows the structure of Indonesia fisheries based on the ownership of the fishing vessel.

Table 1. The category of ownership of fishing vessel in Indonesia

\begin{tabular}{|c|c|c|}
\hline No. & Category & $\begin{array}{c}\text { Number of } \\
\text { Boat }\end{array}$ \\
\hline 1. & Total number of boat & $\mathbf{6 1 8 . 3 2 0}$ unit \\
\hline 2. & Without motor & 165.990 unit $(26,85 \%)$ \\
\hline 3. & Outboard Motors & 252.590 unit $(40,85 \%)$ \\
\hline 4. & $<5 \mathrm{GT}$ & 137.620 unit $(22,26 \%)$ \\
\hline 5. & $5-10 \mathrm{GT}$ & 38.740 unit $(6,27 \%)$ \\
\hline 6. & $10-20 \mathrm{GT}$ & 11.650 unit $(1,88 \%)$ \\
\hline 7. & $20-30 \mathrm{GT}$ & 7.620 unit $(1,23 \%)$ \\
\hline 8. & $30-50 \mathrm{~T}$ & 920 unit $(0,15 \%)$ \\
\hline 9. & $50-100 \mathrm{GT}$ & 1.670 unit $(0,27 \%)$ \\
\hline 10. & $100-200 \mathrm{GT}$ & 1.180 unit $(0,19 \%)$ \\
\hline 11. & $>200 \mathrm{GT}$ & 340 unit $(0,05 \%)$ \\
\hline
\end{tabular}

Source: MOMAF Statistic (2013)

Based on table 1 above, nearly 90 per cent of fishing vessel ownership in Indonesia are dominated by small scale fisheries which is described by the the capacity of vessel. Government Regulation No. 45 Year 2009 stated that small scale fisheries is the fishermen which owned fishing vessel up 
to 5 Gross Tonnes (GT). Fisheries subsidies still needed for fishermen especially small scale fishermen.

Indonesia still want to defending subsidies for small scale fishermen. In the other side, Indonesia should manage the subsidy which is save for the environment. The balance between the environmental protection and the welfare of small scale fishermen become the key of success for the government program in subsidies.

\section{Problem Formulation}

The balance between environmental protection and the welfare of fishermen is the main problem that must be resolved. The balance needs to be reviewed from the use of subsidies carried out in various regions. It needs to be seen further the relationship between the provision of fisheries subsidies with the welfare of fishermen and the preservation of fisheries resources in Indonesia. Based on that, it can be seen the extent of the influence of fishery subsidies.

\section{Material and Methods}

This study focus on literature on fisheries subsidies around the world. The study also analyst the type of the subsidy in Indonesia. It will find the provision of fisheries subsidies by compare the data of the type of the subsidy, fishermen exchange rate and fisheries resources.

Fishermen exchange rate use the data of NTN (Nilai Tukar Nelayan -Fishermens Exchange Ratio). NTN (Nilai Tukar Nelayan- Fishermen Exchange Ratio) is the ratio between the price index received by fishermen (It) and the index the price paid by fishermen (Ib), expressed as a percentage. More than 100 NTN means that fishermen have higher incomes compared to spending, or experiencing a surplus. NTN is lacking of 100 means that fishermen are spending on home consumption ladder and production costs are higher than yield income his effort. ${ }^{6}$

Whereas NTN is equal to 100 it means that operating income is the same as expenses for expenses household consumption and production needs. Fisheries resources refer the data of estimated fisheries resources.

\section{Result}

After conducting a review of the fisheries subsidy scheme provided by the Government of Indonesia (Ministry of Marine Affairs and Fisheries) from 2015 to 2018. The fisheries subsidy was grouped into four types. The four types are:

a. National Fish Logistic System (SLIN)

b. The Development of Community Salt Companies Program (PUGAR)

c. The Fishing Ship Vessels Construction Program

d. Fishers Insurance.

${ }^{6}$ Website of Ministry of Marine Affairs and Fisheries, www.kkp.go.id 
National Fish Logistic System (SLIN) is the subsidy which is purpose to preserve the quality of fish and to strengthen distribution, availability, and accessibility of fish for local consumption. The legislation under which the subsidy is granted are The Regulation of Minister of Marine Affairs and Fisheries No.5/2014 concerning National Fish Logistics System (SLIN). The subsidy is provided to all eligible fishers, in particular those who are in remote areas, in the form of cold chain system facilities and infrastructure. Duration of the subsidy are from 2015 to 2018.

The Development of Community Salt Companies Program (PUGAR) is the subsidy which is purpose to To improve the welfare of salt farmers, increase salt productivity and quality and to improve salt farmers' skill. The legislation under which the Subsidy is granted are Law No. 7/2016 concerning the Protection and Empowerment of Fishers, Fish Cultivators and Salt Farmers, The Regulation of Minister of Marine Affairs and Fisheries No. 18/2016 concerning the Guarantee of Risk Protection for Fishers, Fish Farmers and Salt Farmers, The Regulation of Minister of Marine Affairs and Fisheries No. 60/2017 concerning the amendment of the Regulation of Minister of Marine Affairs and Fisheries No. 70/2016 concerning The General Guidelines for the Distribution of Government Assistances in the Ministry of Marine Affairs and Fisheries. The subsidy is provided to all eligible salt farmers, in the form of facilities and infrastructure for community salt company. Duration of the subsidy are from 2015 until present. The subsidy is not related to international trade.

The Fishing Ship Vessels Construction Program is the subsidy which is purpose to improving the welfare of small fishers with limited business capital and providing access to utilize the potential of fish resources while remain maintaining the sustainability of fish resources. The legislation under which the Subsidy is granted are Law No. 7/2016 concerning the Protection and Empowerment of Fishers, Fish Cultivators and Salt Farmers, The Regulation of Minister of Marine Affairs and Fisheries No. 60/2017 concerning the amendment of the Regulation of Minister of Marine Affairs and Fisheries No. 70/2016 concerning The General Guidelines for the Distribution of Government Assistances in the Ministry of Marine Affairs and Fisheries. The subsidy is provided to all eligible small fishers. The subsidy is provided in the form of fishing vessel, fishing vessels machines, and environmental friendly fishing gears. Duration of the subsidy are from 2015 until present.

Fishers Insurance is the subsidy to introduce advantages of fishers insurance regarding risk protection for fishing accidents at sea, promote awareness for fishers on the importance of insurance and to encourage self-insurance. The legislation under which the Subsidy is granted are Law No. 7/2016 concerning the Protection and Empowerment of Fishers, Fish Cultivators and Salt Farmers, The Regulation of Minister of Marine Affairs and Fisheries no. 18/2016 concerning Life Insurance for Fishers, Fish Farmers, and Salt Farmers, The Regulation of Minister of Marine Affairs and Fisheries No. 60/2017 concerning the amendment of the Regulation of Minister of Marine Affairs and Fisheries No. 70/2016 concerning The General Guidelines for the Distribution of Government Assistances in the Ministry of Marine Affairs and Fisheries. The subsidy is provided to small fishers ( $<10$ GT); small fishers who have a valid fisher card (KUSUKA); and small fishers who do not use prohibited fishing gears. The payment of life insurance premium will be only provided for the first year. Duration of the subsidy are from 2016 until present.

After discussing one by one regarding the fishery subsidies provided by the Government of Indonesia in this case the Ministry of Maritime Affairs and Fisheries, the provision of these subsidies is compared to the development of the welfare level of fishermen. The welfare level use the data of NTN (Nilai Tukar Nelayan -Fishermens Exchange Ratio). 
The data of NTN from 2014 is 102,68, 2015 is 102,39, 2016 is 102,85, 2017 is 104,05 and 2018 is 105,99 . The increase of NTN reflects the level of welfare of fishermen increasing every year. This is a proof that fishery subsidies have an impact on the welfare of fishermen.

\section{Discussion}

The debate on fisheries subsidies has been raised to the level of the World Trade Organization (WTO). WTO has even encouraged discussion of fisheries subsidies as one of the disciplines that must be specially arranged. Since the WTO $4^{\text {th }}$ Ministerial Conference in Doha 2001, fisheries subsidies keep rolling into a crowded issue discussed.

The informal group Friends of the Fish in WTO states that fisheries subsidies should be removed for cause overfishing and overcapacity lever the issue until the last Ministerial Conference. Based on the FAO report (2010), nearly 80 percent of the waters around the world are experiencing the overexploited condition. The report referenced by various groups including Friends of the Fish to urge the immediate enactment of fisheries subsidies into one of disciplines in the WTO.

In the $11^{\text {th }}$ WTO Ministerial Conference at December 2017 in Buenos Aires, Argentina, the Ministers of member countries agreed on one of Indonesia's proposals regarding fishery subsidies that can be given to small-scale and artisanal fishermen. The negotiations also agreed that the next meeting would discuss provisions leading to the prohibition of subsidies on industrial scale vessels ${ }^{7}$ (Ministry of Trade: 2017). Other agreements were reached by WTO Member Ministers to meet the Sustainable Development Goals (SDGs) target and strengthen fishery subsidy transparency. The agreement of the Ministers of the WTO members is contained in the Ministerial Decision on Fisheries Subsidies.

Although one of Indonesia's proposals was agreed upon, it seems that Indonesia's negotiations on fishery subsidies still require time. The different interests and views of each country complicate the agreement process regarding fisheries subsidies at the WTO. Ahead of the $12^{\text {th }}$ WTO Ministerial Conference in the end of this year, negotiations on the prohibition of fishery subsidies will still be a work that needs to be completed. There is still a long way to go to reach the agreement.

Until now the discussion of fisheries subsidies still encounter barriers due to conflicts of interest between countries. Indonesia itself is still seeking a balance between the demands of economic development and improving the welfare of fishermen with the problem of sustainability of fish resources. In-depth study are required to fulfill "the needs of balance" in the fisheries subsidies.

Indonesia still needs to maintain the provision of subsidies in the fisheries sector because many people still depend on fisheries sector. It should be noted that $80 \%$ of the total Indonesian fishermen are live below the poverty line. On the other hand, it is recognized that some types of fisheries subsidies could threaten the sustainability of marine resources. Therefore, they need a balanced arrangement that both these interests can work well together.

In the ongoing negotiations, the countries are aware that the WTO is not only focused on trade but also focuses on environmental issues, particularly the optimal use of resources for sustainable development. Indonesia itself has submitted several proposals regarding some important things in the interest of Indonesia and also developing countries, including among others:

\footnotetext{
${ }^{7}$ Ministry of Trade: 2017
} 
a. Special and Differential Treatment, in this case, Indonesia trying to get subsidies to artisanal fishing, small fishermen, ZEE developing countries, and the regional fishery management plans, still allowed.

b. Technical Assistance, that the developing countries need technical assistance in initiating, implementing and executing, and developing a fishery management plan. In addition, assistance to participate in RFMO and to establish inquiry points.

c. The concept of adverse effect on fisheries resource that does not exist in the ASCM for the analysis of actionable subsidy, and two remedies, namely through the domestic track and the multilateral track.

Other countries actively participate in providing proposals regarding discipline in this field. In 2007, WTO has published the Draft Chair's Text that has been commented upon by the states through their proposals. Especially for the Special and Differential Treatment, WTO members have not reached an agreement because many developing and least-developed countries where people still depend on the fisheries sector. Many of them still need a subsidy from the government to support themselves and their families.

There are some research on fisheries subsidies. Schachermayer [1] stated in his research that the subsidy does not have a positive impact on improving the welfare of fishermen and ecological protection. UNEP [2] in its annual report 2001 entitled Fisheries Subsidies and Marine Resource Management: Lessons Learned from studies in Argentina and Senegal expressed the same thing that fisheries subsidies no positive impact on the welfare of fishermen.

Porter $^{8}$ present a similar case but stated that if the fisheries subsidies given to fishermen for transition job to another job outside of the fishing, then it is a positive impact on the protection of fish resources. Sumaila et al. [3] stated that the fuel subsidy is a subsidy given to most fishermen around the world and should be reduced or discontinued to encourage the sustainability of natural resources.

Harpera (2012) supports research Sumaila on fuel subsidy removal. Additionally, Harpera [4] states that the provisions of the exemption in the draft text chair in the WTO fisheries subsidies can lead countries like the United States to exploit the gaps interests, such as the tax exemption for the fisherman who is one of the forms of fisheries subsidies.

Stokke and Coffey [5] stated that the need to cross-institutional learning related fisheries subsidies due to the lack of a strong compliance mechanisms in the WTO. Gooday [6] stated that Fisheries Subsidies convey about the discipline in terms of various perspectives of international cooperation organizations such as the OECD, APEC and WTO.

Cox [7] stated that removing or reducing the subsidy will reduce the pressure of stock to some extent although it will not remove it completely. Subsidy reform program and improved management and enforcement at sea must take place simultaneously.

In line with Cox, Jinji [8] stated that the effect of the reduction of fisheries subsidies on the output will be different, depending on economic conditions and the management of fisheries in various countries. Fisheries output will increase in countries where the catch quotas are not enforced and remained the same in countries where the catch quota is strictly regulated. In the short term, need to expand the total supply of fishery products and in the long term, the stock of world fishery resources

${ }^{8}$ Porter, Gareth (2001). Fisheries Subsidies and Overfishing: Towards a Structured Discussion. UNEP Report 
can be reduced. The key is how the changes will affect the incentive subsidy of workers involved in the fishery.

Orellana [9] states that fisheries access agreement being a hindrance to the process of negotiations among WTO members, especially for small coastal states. These countries are worried that capital flows will stop when they are exposed to the subject of WTO disciplines. Research suggests that fisheries access agreements do not violate the ASCM. In another study, Orellana ${ }^{9}$ addressed the alternatives middle ground on Fishing Access Agreements in the Exclusive Economic Zone with Fisheries Subsidies in the WTO Agreements.

Jacquet and Pauly [10] in their study mentioned that most of the fisheries subsidies touch largescale fisheries. Ecolabel certificate of no significant impact for the management of fisheries resources is sustainable because it does not touch on the small-scale fisheries. Fisheries subsidies are harmful to the environment should be eliminated. In line with Jacquet and Pauly,

Different opinions expressed by Tallontire [11] who said that the subsidies do not necessarily have a negative impact on overfishing and the environment. The presence of an effective fisheries management and sustainable is seen by Tallontire more important. Therefore, Special and Differential Treatment required by developing countries in the WTO fisheries subsidies disciplines.

Subsidies have contributed positively to the increase in fish production and export capacity in Indonesia. These condition is reflected on the fact that fish production and fisheries export are inclining continously.

Indonesia should be aware that such subsidies many more enjoyed by large-scale fishermen. This is happen because:

a. Most of the small-scale fishermen do not enjoy subsidized diesel because they have to buy oil at a price of non-subsidized from retailers outside the gas station because of the limited supply of oil and the arrival time is uncertain supply. Even the subsidized diesel often been absorbed by the large-scale fishermen, fishing industry and retailers syndicate.

b. Subsidy recipients apparently were not fishermen but many people who have close relations with the authorities dealer distribution. This is because the selection process was not transparent subsidy recipients and selective logging.

c. Form of subsidy is not given as required by the fishermen.

d. Received subsidies absorbed by the costs to be paid fishermen for fishing activities to a collector who has financed the first fishing capital, which also determines the selling price of fish the fishermen.

Basically for a balanced arrangement, Indonesia has had the Law No. 45 of 2009 on the amendment of Law No. 31 of 2004 and its implementing regulations regarding the management of fish (Fishery Management). These laws regulate fisheries management aimed to achieve sustainable productivity of aquatic biological resources, including:

${ }^{9}$ Orellana, Marcos A. (2008). Towards Sustainable Fisheries access agreements, Issues and Options at the World Trade

Organization. Center for International Environmental Law (CIEL), Commissioned by The United Nations

Environment Programme (UNEP) \& Economics and Trade Branch (ETB) Geneva 
a. Custom-based Fisheries Management (Indigenous Fishery Management).

b. Public awareness based Fisheries Management to preserve the fishery in the coastal region where they lived.

c. Community-based fisheries management (Panwasmas) formed by the local government throughout the study area, which consist of Police and the representative of the Fishermen.

Provision of subsidies in the fisheries sector is not referring to the specific patterns that the balance between the increase in the welfare of small fishing with the protection of fisheries resources. Ideally, there is a special formula which governs the granting of subsidies and the allocation to fishermen's welfare fisheries resources and can go hand in hand. The formula should pay attention to the principles of sustainable development that is socially acceptable, economically profitable, environmentally sustainable and technologically manageable.

The problem is there is no special formula like that in Indonesia. Ministry of Maritime Affairs and Fisheries as the lead sector subsidization programs still rely on the conventional pattern of such subsidies fuel oil for fishermen, fishing vessels as well as the provision of fishing gear and others.

The research in Indonesia can refer to Thi Duy Thanh Phama et. al (2013) and adjust with the condition in Indonesia. It is because Indonesia is not only the biggest archipelagic state in the world and also has more small scale fishermen. The support from government as subsidy still needed by small scale fishermen in Indonesia.

\section{Conclusion}

Fisheries subsidies are very important for countries whose population is heavily dependent on the fisheries sector. The thing to considered is the inappropriate mechanism may cause the subsidy is not well targeted and have a negative impact on the environment.

Indonesia need to formulate the right concept of fisheries subsidies based on the interests of small scale fishermen. It is very important to the position of Indonesia in WTO, particularly developing countries. Sumaila (2014) showed that fisheries subsidies apparently more widely enjoyed by fishermen from developed countries due to operational transfer to fishing vessels that increase boat efficiency. Future studies are recommended to find a formula of the balance between environmental protection by improving the welfare of fishermen.

\section{References}

[1] Annual Report of Ministry of Trade Republic of Indonesia. (2017)

[2] Fauzi, Achmad (2011). Ekonomi Perikanan. Jakarta: Penerbit Kompas Gramedia

[3] Harpera, Sarah, Bevacquab, Daniele, Chudnowc, Rachel, Giorgid, Sabrina, Guillonneaud, Victoire, Le Manache, Frédéric, Sutorf, Tim, Sumaila, Ussif Rashid. Fuelling the fisheries subsidy debate: Agreements, loopholes and implications. Fisheries Research 113 143- 146 (2012)

[4] Jacquet, Jennifer \& Pauly, Daniel. Funding Priorities: Big Barriers to Small-Scale.Fisheries Conservation Biology. Volume 22, No. 4, 832-835 (2008) 
[5] Jinji, Naoto. Fisheries Subsidies and Management in Open Economies. Marine Resource Economics, Volume 27, pp. 25-41 (2012)

[6] Law No. 7/2016 concerning the Protection and Empowerment of Fishers, Fish Cultivators and Salt Farmers

[7] Law No. 45 tahun 2009 regarding the concerning Amendment to Law No. 31 of 2004 concerning Fisheries

[8] Minister of Marine Affairs and Fisheries Decree No. 47/KEPMEN-KP/ 2016 concerning Estimation of

Potential, Number of Catches Allowed, Level of Utilization of Fish Resources in the State Fisheries Management

Area of the Republic of Indonesia

[9] Minister of Marine Affairs and Fisheries Decree No. 50/KEPMEN-KP/ 2017 concerning Estimation of

Potential, Number of Catches Allowed, Level of Utilization of Fish Resources in the State Fisheries Management

Area of the Republic of Indonesia

[10] Minister of Marine Affairs and Fisheries Regulation No. 1/2009 regarding Regional Fisheries Management of

the Republic of Indonesia

[11] Minister of Marine Affairs and Fisheries Regulation No.5/2014 concerning National Fish Logistics System

(SLIN)

[12] Minister of Marine Affairs and Fisheries Regulation No. 18/2016 concerning the Guarantee of Risk Protection

for Fishers, Fish Farmers and Salt Farmers

[13] Minister of Marine Affairs and Fisheries Regulation No. 60/2017 concerning the amendment of the Regulation

of Minister of Marine Affairs and Fisheries No. 70/2016 concerning The General Guidelines for the Distribution

of Government Assistances in the Ministry of Marine Affairs and Fisheries

[14] OECD. Subsidies and Environment. Exploring the Linkages. OECD, Paris. (1996)

[15] Orellana Marcos A. EEZ Fisheries Access Arrangements and the WTO Subsidies Agreement:Legal Analysis

and Options for Improved Disciplines. Center for International Environmental Law (CIEL), Commissioned by The

United Nations Environment Programme (UNEP) Economics and Trade Branch (ETB) Geneva. (2008)

[16] Orellana, Marcos A. Towards Sustainable Fisheries access agreements, Issues and Options at the World Trade Organization. Center for International Environmental Law (CIEL), Commissioned by The United Nations Environment Programme (UNEP) \& Economics and Trade Branch (ETB) Geneva. (2008)

[17] Pham, Thi Duy Thanh, Hsiang-Wen Huang, and Ching-Ta Chuang. "Finding a balance between economic performance and capacity efficiency for sustainable fisheries: Case of the Da Nang gillnet fishery, Vietnam", Marine Policy 44. 287-294. (2013) 
[18] Porter, Gareth. Fisheries Subsidies and Overfishing: Towards a Structured Discussion. UNEP Report. (2001)

[19] Schachermayer, Carolin I. Mondaca, Aburto Jaime, Cundill, Georgina, Lancellotti, Carlos, Domingo \& Tapia. An Empirical Analysis of the Social and Ecological Outcomes of State Subsidies for Small-Scale Fisheries: A Case Study from Chile. Ecology and Society 16(3): 17. (2011)

[20] Tallontire, Anne. The Impact of Subsidies on Trade in Fisheries Products. Food and Agriculture Organization (FAO) of the United Nations, Rome Project PR 26109. (2004)

[21] Thi Duy Thanh Phama, Hsiang-Wen Huangbin, Ching-Ta Chuang. Finding a balance between economic performance and capacity efficiency for sustainable fisheries: Case of the $\mathrm{Da}$ Nang gillnet fishery, Vietnam. Marine Policy 44. 287-294. (2014)

[22] United Nations, Report of The World Commission on Environment and Development: Our Common Future, 1987

[23] United Nations Environmental Programme. Fisheries Subsidies and Marine Resources Management: Lessons learned from Studies in Argentina and Senegal. 2001.

[24] van Beers, C., van den Bergh, J. Perseverance of perverse subsidies and their impact on trade and environment. Ecological Economics 36, 475-486. (2001)

[25] van Beers, C., van den Bergh, J. An Overview of methodological approaches in the analysis of trade and environment. J. World Trade 30, 143-167. (1996)

[26] www.kkp.go.id 